\title{
EFFECTS OF PERENNIAL FIRES ON THE WOODY VEGETATION OF MOLE NATIONAL PARK, GHANA
}

\author{
I. Sackey ${ }^{1}$ and W. H. G. Hale ${ }^{2}$ \\ ${ }^{1}$ Department of Applied Biology, \\ University for Development Studies, \\ P.O. Box 1350, Tamale, Ghana \\ ${ }^{2}$ Department of Geography and Environmental Science, \\ University of Bradford, Bradford, BD7 1DP, United Kingdom
}

\begin{abstract}
Recurrent fires have a considerable potential to influence the structure and composition of savanna vegetation. In Mole National Park in Ghana, the policy is to burn the vegetation annually early in the dry season. This study aimed to assess the effects of these perennial fires on the trees and shrubs of the Park. To achieve this, scars on tree bole bases as well as mortality and top-kill to trees $\geq 2 \mathrm{~m}$ tall resulting from perennial fires were assessed in twenty $50 \mathrm{~m} \times 50 \mathrm{~m}$ plots in the savanna vegetation near Grupe camp at the south-western section of the Park. Fire scars on tree bole bases were widespread, but were significantly more frequent on large trees (> $5 \mathrm{~m}$ tall) than small ones $(<2 \mathrm{~m}$ tall). Also, certain tree species, notably Burkea africana and Detarium microcarpum were more prone to scarring. The greater proportion of the scars had reached an advanced stage and the affected individuals were either moribund or were likely to be killed by subsequent fires or toppled by the wind. Contrary to the popular opinion that fire generally affects tree recruitment and not adult survival, fire-induced mortality and top-kill to large trees (> $5 \mathrm{~m}$ tall) was widespread among all the tree species, particularly Acacia dudgeoni, Burkea africana, Detarium microcarpum and Vitellaria paradoxa. These fire impacts will likely lead to changes in the relative abundance of the constituent tree species as well as a decline in the density of woody elements in the plant community as a whole unless burning frequency is reduced. The areas for which these predicted vegetation changes are valid can be generalized to include the vegetation in the northern half of the Park where similar conditions of high fuel load and intense fires are likely to prevail.
\end{abstract}

Keywords: Savanna woodland, fire impacts, basal scars, vegetation changes

\section{INTRODUCTION}

Frequent fires are a serious environmental problem in many tropical savannas throughout the world, and have in many instances resulted in declines in woody elements and consequently caused vegetation transformation from woodland to grassland in Africa. Savanna tree communities exhibit a high degree of resilience to individual

36 Journal of Science and Technology, Vol. 28, No. 2, August, 2008 
fires (Felfili et al., 2000), presumably due to the low mortality and rapid re-sprouting (Rutherford, 1981; Trollope, 1996). However, even low rates of mortality may not be sufficient to guarantee persistence under frequent burning. Low rates of fire-induced mortality, compounded over multiple fires can cause considerable loss, while many of those individuals that survive burning are subjected to top-kill.

Large individuals may resist top-kill or outright mortality due to thick bark, but small individuals cannot (Rutherford, 1981; Gignoux et al., 1997). If burning is frequent, these small individuals may not be able to grow into large-sized trees, remaining indefinitely in a reduced stage. Similarly, even some large, mature individuals may be subjected to top-kill (Williams et al., 1999), thus reverting to a small size, with this reduction being effectively irreversible if fire is too frequent. These reduced individuals will remain in this state unless a sufficiently long fire-free interval occurs to allow them to attain sufficient size and bark thickness to resist top-kill. Therefore, top-kill, the rate of re-sprout development (Higgins et al., 2000) and mortality may control changes in tree cover in moist tropical savannas.

In Mole National Park, the policy is to burn the vegetation annually early in the dry season when the grass fuel is still moist, presumably to achieve a low fire intensity and thus minimise its impact on the Park's vegetation. It is, however, certain that late dry season fires occur regularly over large areas of the Park. Information on the effects of fire on the vegetation of Mole is virtually non-existent. This study thus aimed to assess the impact of these managed annual fires on trees and shrubs in the south-western section of Mole (Figure 1). The vegetation in this section of the Park is virtually devoid of elephants as well as other large mammalian herbivores and, thus, offered a unique opportunity to assess the effects of fire on woody plant structure and composition in isolation from herbivory impacts, which often complicates the interpretation of the results of most experiments on fire in savannas.

\section{MATERIALS AND METHODS}

\section{Study area}

Mole National Park is situated in northern Ghana between $9^{\circ} 12^{\prime}-10^{\circ} 06^{\prime}$ North and $1^{\circ} 25^{\prime}-2^{\circ} 17^{\prime}$ West and covers an area of approximately 4840 $\mathrm{km}^{2}$. The Mole and Lovi rivers are the most significant among the numerous rivers which cross or originate in the Park. A climatic diagram for the nearest meteorological station, Damongo, about $18 \mathrm{~km}$ south of Mole, is shown in Figure 2. More than $95 \%$ of the mean annual rain (1098.1 \pm $78.3 \mathrm{~mm}$ ) falls during the single rainy season from April to October, with maxima occurring in July and the prime peak in September. The five consecutive months of the dry season (November - March) have a mean total rainfall of $49.7 \pm 3.2$ $\mathrm{mm}$. The mean annual temperature of $27.7^{\circ} \mathrm{C}$ varies little from month to month $\left(25.7-31.0^{\circ}\right.$ $\mathrm{C})$, while the average diurnal range is $13.3^{\circ} \mathrm{C}$.

The Park lies in the Guinea savanna zone. The dominant vegetation type is the open savanna woodland with a grass layer that can reach up to 3 $\mathrm{m}$ tall during the rainy season and which is burnt annually. Hall and Jeník (1968) have recognised four savanna vegetation types in the West Gonja District, which includes the Park. These are the Terminalia macroptera-Loudetiopsis thorolditype in badly-drained and seasonally flooded plains, the Mitragyna inermis-Andropogon gayanus var. gayanus-type in valley bottoms along streams, the Isoberlinia doka-Loudetiopsis scaethae-Hyperrhenia subplumosa-type on gentle slopes and well-drained plains and the Loudetiopsis kerstingii-Polycarpea tenuifoliatype on iron stone plateaux.

There are about 94 species of mammals (including bats) and over 300 species of birds in the Park (Hossain and Hall, 1996). The distribution of large mammals, particularly elephants, is skewed to the south-eastern section of the Park (Figure 1). This study was conducted in the south -western section of the Park where elephants as well as other large mammals are virtually absent for most part of the year. The savanna vegetation in the area is largely the Isoberlinia doka- 


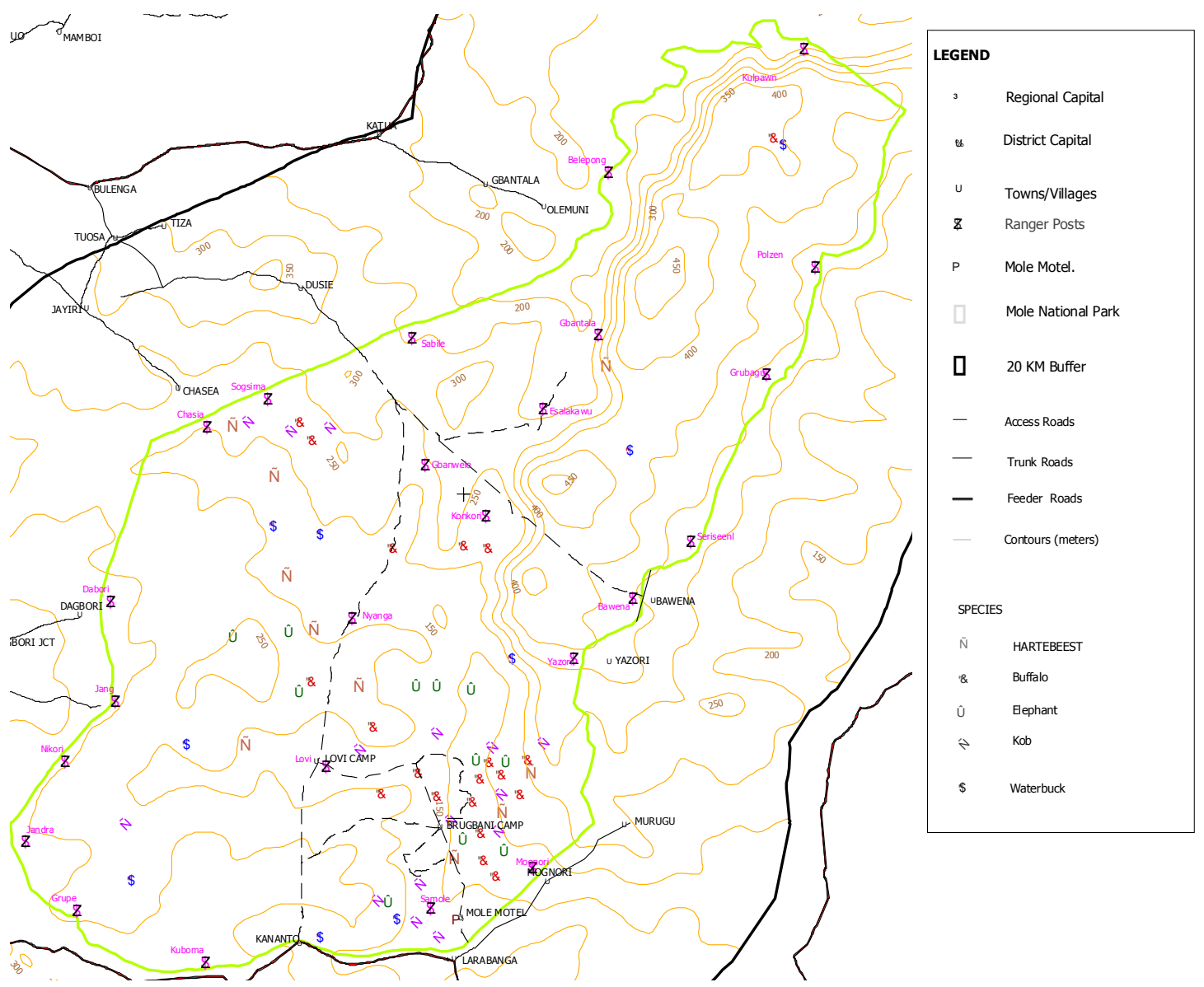

Fig. 1: Map of Mole National Park showing the distribution of some selected large mammals and sampling site edged red. Reproduced with permission from the Centre for Remote Sensing and Geographic Information Services (CERSGIS) of the University of Ghana, Ghana.

Loudetiopsis scaethae-Hyperrhenia subplumosa subtype of Hall and Jeník (1968). Further details of the Mole National Park are included in Sackey (2006).

\section{Field data collection}

The field work was carried out in April, 2004, a few weeks after the annual burning of the vegetation of the study area had taken place. Unfortu- nately, this meant that the opportunity to assess the effects of one season of burning on woody plant species, especially small-sized individuals was missed. In the determinations, no distinction could be made regarding the exact number of fire occurrences responsible for the various forms of damage observed to have been inflicted on the tree/shrub sample. Furthermore, the assessment was confined to trees/shrubs $\geq 2 \mathrm{~m}$ tall. 


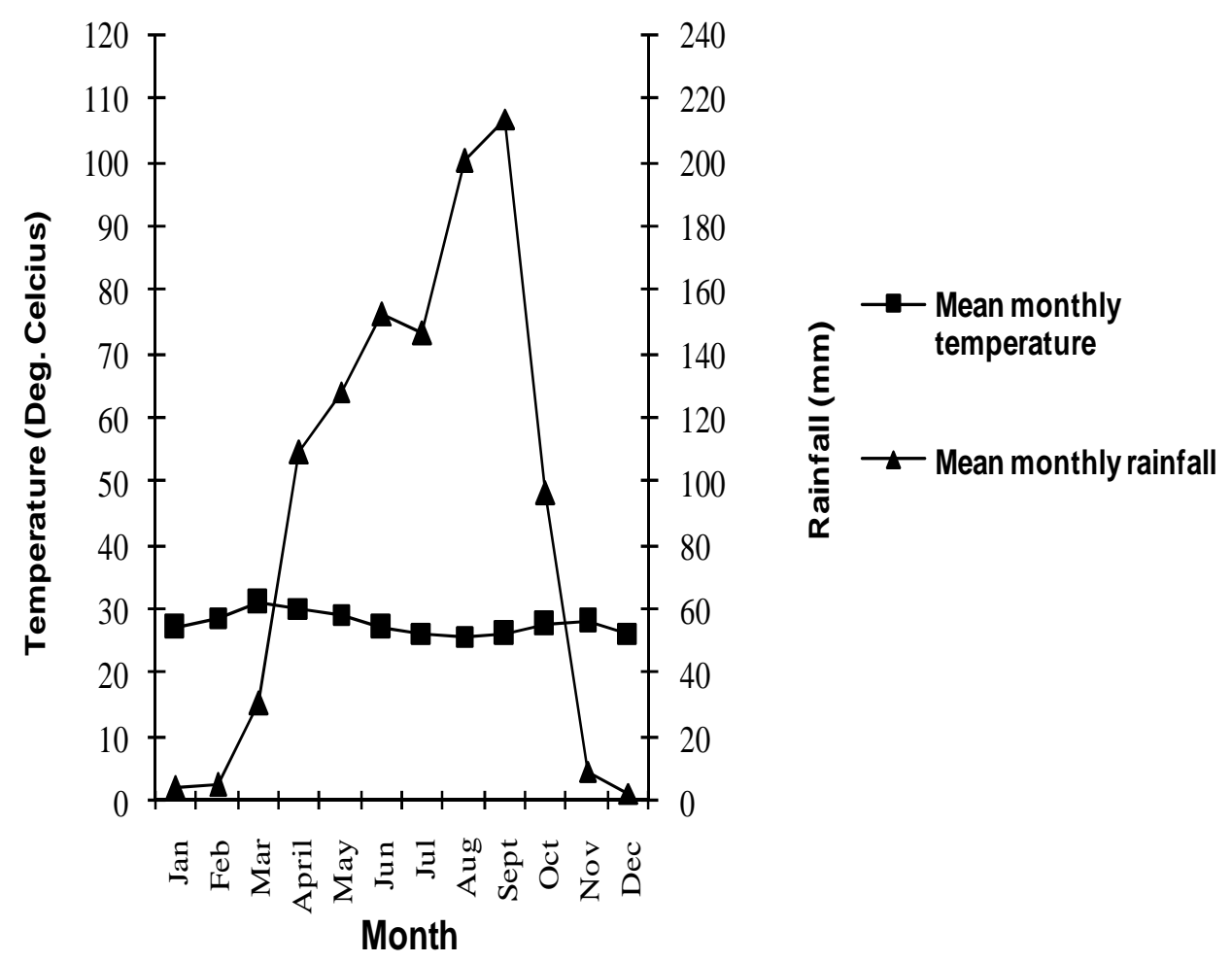

Fig. 2: Climatic diagram for Damongo, Ghana, based on rainfall data from 1985-2003 and temperature data from 1998-2003. Source of data: Ghana Meteorological Services

Fire damage on trees and shrubs was carried out in twenty $50 \mathrm{~m}$ x $50 \mathrm{~m}$ plots contiguously located approximately perpendicular to a footpath as a baseline. Due to the difficulty in distinguishing between dead and burnt trees of Terminalia avicennioides and Terminalia laxiflora as well as Parinari polyandra and Parinari curatelifolia, individual trees of these species were recorded, respectively, as Terminalia spp. and Parinari spp.

\section{Dead and top-killed trees/shrubs}

Dead trees ('Root kill' of Niering et al., 1970) were defined as involving complete mortality of the stems and roots of the plants, while top- killed trees ('Stem kill' of Niering et al., 1970) were defined as involving mortality of only the aerial parts of the plants. Every individual tree/ shrub was assessed for growth condition and placed into one of the following categories: dead; top-killed and re-sprouting; and living. The height of trees/shrubs was measured to the nearest $20 \mathrm{~cm}$ using either a wooden height pole (for trees up to $5 \mathrm{~m}$ tall) or a SUUNTO clinometer (for trees over $5 \mathrm{~m}$ tall). For trees with a dead trunk, their height was measured up to the highest branch or twig, while height measurement for those with a broken trunk was determined as the sum of the length of the broken trunk and that of the stump. 


\section{Basal scarring damage on trees}

Trunks of all living trees of height $2 \mathrm{~m}$ tall or more were examined for basal scarring damage. The height of the trees was measured to the nearest $20 \mathrm{~cm}$ using a wooden height pole or a clinometer. Furthermore, the degree of basal scarring damage as well as their orientation on trees over $5 \mathrm{~m}$ in height was assessed visually. The scar damage was categorized as follows: class i: up to $1 / 4$ of the tree bole circumference scarred; class ii: $1 / 4$ to $1 / 2$ of the bole circumference scarred; and class iii: $>1 / 2$ of the bole circumference scarred.

\section{Data analysis}

To correct for density differences among the different tree species and tree height classes, the data were analysed in the form of proportions and arcsin transformed. Differences in the frequency of fire impacts among trees species and tree height classes were compared by $t$-tests using the transformed data (Sokal and Rohlf, 1995). The orientation of basal scars was assessed statistically by chi-square tests.

\section{RESULTS}

In total, 2696 trees and shrubs $\geq 2 \mathrm{~m}$ tall belonging to 46 species and 38 genera were examined for fire damage. Approximately $83.7 \%$ of this sample was $2-5 \mathrm{~m}$ tall, while $16.3 \%$ was $>5 \mathrm{~m}$ in height. Approximately $13.3 \pm 0.2 \%$ ( $1 \mathrm{~S}$. E.) of all the trees were either dead $(8.6 \pm 0.1 \%)$ or had been top-killed $(4.4 \pm 0.2 \%)$ by fire and were resprouting from the stem bases or stumps or roots, while $86.7 \pm 0.2 \%$ had the main trunk living. Of this latter sample of trees, $22.0 \pm 0.4 \%$ had various degrees of fire scarring damage at the stem bases, while the greater proportion $(78.0 \pm 0.4 \%)$ were classified as 'healthy', though their barks were superficially scorched from fire. Some, especially those of relatively short growth form, also had scorched leaves and twigs/branches.

\section{Dead trees}

Approximately $8.6 \pm 0.1 \%$ ( $1 \mathrm{~S}$. E.) of all the recorded trees were dead, including 15 trees which had been toppled by wind and subsequently burnt by fire (Plate 1). Most of the tree species were represented by a few individuals. For the relatively abundant species, the relative proportion of dead individuals was variable among them (Table 1). Comparison of the proportion of dead trees between six main species by a series of paired $t$ tests did not show any significant difference between them $(p>0.05)$. The relative proportion of the dead trees measuring over $5 \mathrm{~m}$ tall $(29.9 \pm$

Table 1: Number and relative proportion of stems of six main tree species completely killed by fire in the upper- to middle-slope savanna near Grupe Camp in Mole National Park according tree height class. All the values are expressed at $95 \%$ confidence level

\begin{tabular}{|c|c|c|c|c|c|c|}
\hline \multirow[b]{2}{*}{ Tree species } & \multicolumn{2}{|c|}{$2-5 m$ tall } & \multicolumn{2}{|c|}{$5 m$ tall } & \multirow[b]{2}{*}{$\begin{array}{c}\text { Total } \\
\text { No. }\end{array}$} & \multirow{2}{*}{$\begin{array}{c}\text { Relative } \\
\text { proportion } \\
(\%)\end{array}$} \\
\hline & $\begin{array}{l}\text { No. of } \\
\text { stems } \\
\text { killed }\end{array}$ & $\%$ & $\begin{array}{l}\text { No. of } \\
\text { stems } \\
\text { killed }\end{array}$ & $\%$ & & \\
\hline Acacia dudgeoni & 12 & $1.5 \pm 1.3$ & 5 & $93.3 \pm \mathbf{2 8 . 6}$ & 17 & $3.5 \pm 1.4$ \\
\hline Burkea africana & 19 & $8.3 \pm 6.5$ & 65 & $53.5 \pm 6.5$ & 84 & $30.2 \pm 7.1$ \\
\hline Combretum adenogenium & 21 & $2.2 \pm 1.1$ & 9 & $10.2 \pm 9.5$ & 30 & $3.5 \pm 1.0$ \\
\hline Detarium microcarpum & 6 & $0.5 \pm 1.2$ & 17 & $26.8 \pm 10.5$ & 23 & $5.3 \pm 2.3$ \\
\hline Terminalia spp. & 3 & $5.8 \pm 7.8$ & 1 & $11.1 \pm 5.2$ & 4 & $6.6 \pm 7.8$ \\
\hline Vitellaria paradoxa & 19 & $1.6 \pm 1.3$ & 15 & $15.2 \pm 7.5$ & 34 & $4.0 \pm 1.4$ \\
\hline
\end{tabular}

40 Journal of Science and Technology, Vol. 28, No. 2, August, 2008 
$0.8 \%$ ) was significantly higher than the proportion $(4.0 \pm 0.2 \%)$ of dead trees measuring $2-5 \mathrm{~m}$ tall $(t=13.88$; d.f. $=38 ; p<0.001)$. A similar trend was observed for all the six individual species (Table 1).

\section{Top-killed trees}

Approximately $4.4 \pm 0.2 \%$ (1 S. E.) of the 2696 trees and shrubs examined for fire damage had been top-killed but had re-sprouted from either the stem bases or roots or stumps. Included in this sample were seven trees, five of which were large Burkea africana trees, which had been toppled by wind and the main trunk burnt by fire. All the five Burkea africana trees had been toppled in the rainy season preceding the study and still had moist and intact barks. The relative proportion of top-killed trees $>5 \mathrm{~m}$ tall $(8.0 \pm$ $1.0 \%$ ) was significantly higher than that of topkilled individuals measuring $2-5 \mathrm{~m}$ tall $(3.2 \pm$ $0.3 \%)(t=2.07$; d.f. $=38 ; p<0.05)$. A similar trend was observed for most of the more common species (Table 2).

Fire scarring damage on tree bases In total, 1913 living stems, belonging to 27 spe- cies, were examined for basal scar damage, of which $1658(86.7 \%)$ and $255(13.3 \%)$ were $2-5 \mathrm{~m}$ and $>5 \mathrm{~m}$ tall, respectively. Of this total sample of living trees, $22.0 \pm 0.4 \%$ ( $1 \mathrm{~S}$. E.) were basally scarred of which $67.0 \%$ and $33.0 \%$ were $2-5 \mathrm{~m}$ and $>5 \mathrm{~m}$ tall, respectively. Within tree height, scarring damage was significantly more frequent in larger trees than small ones $(t=6.79$; d.f. $=30$; $p<0.001)$. About $56.7 \pm 2.5 \%$ of all trees over 5 $\mathrm{m}$ tall had basal scars, compared with $17.3 \pm$ $0.6 \%$ for trees measuring $2-5 \mathrm{~m}$ in height.

Most of the species had too few scarred trees to be considered individually. For the five most commonly scarred species, the frequency of basal scars was variable among them (Table 3). Basal scarring was significantly more frequent in Burkea africana than in Acacia dudgeoni ( $t=$ 5.22 ; d.f. $=30 ; p<0.001)$, Combretum adenogonium ( $t=4.72$; d.f. $=30 ; p<0.001)$ and Vitellaria paradoxa $(t=4.68$; d.f. $=30 ; p<0.001)$. Similarly, the frequency of basal scarring damage in Detarium microcarpum was significantly higher than Acacia dudgeoni $(t=4.60 ;$ d.f. $=30 ; p<$ $0.001)$, Combretum adenogonium $(t=4.19$; d.f. $=$ $30 ; p<0.001)$ and Vitellaria paradoxa $(t=4.17$ d.f. $=30 ; p<0.001)$. The frequency of basal scar-

Table 2: Number and relative proportion of stems of six main tree species top-killed by fire in the upper- to middle-slope savanna near Grupe camp in Mole National Park according to tree height class. All the values are expressed at $95 \%$ confidence level

\begin{tabular}{|c|c|c|c|c|c|c|}
\hline \multirow[b]{2}{*}{ Tree species } & \multicolumn{2}{|c|}{$2-5 m$ tall } & \multicolumn{2}{|c|}{$5 \mathrm{~m}$ tall } & \multirow[b]{2}{*}{$\begin{array}{c}\text { Total } \\
\text { No. }\end{array}$} & \multirow[b]{2}{*}{$\begin{array}{c}\text { Relative } \\
\text { proportion } \\
(\%)\end{array}$} \\
\hline & $\begin{array}{c}\text { No. of } \\
\text { stems } \\
\text { top- } \\
\text { killed }\end{array}$ & $\%$ & $\begin{array}{c}\text { No. of } \\
\text { stems } \\
\text { top- } \\
\text { killed }\end{array}$ & $\%$ & & \\
\hline Acacia dudgeoni & 7 & $0.4 \pm 0.8$ & 1 & $6.7 \pm 28.6$ & 8 & $0.6 \pm 0.9$ \\
\hline Burkea africana & 5 & $0.6 \pm 1.2$ & 11 & $5.0 \pm 2.6$ & 16 & $2.7 \pm 1.2$ \\
\hline Combretum adenogenium & 17 & $1.9 \pm 0.9$ & 4 & $1.4 \pm 3.3$ & 21 & $2.4 \pm 0.9$ \\
\hline Detarium microcarpum & 1 & $0.02 \pm 0.2$ & 2 & $0.3 \pm 1.1$ & 3 & $0.1 \pm 0.3$ \\
\hline Terminalia spp. & 9 & $17.3 \pm 9.6$ & 2 & $22.2 \pm 19.1$ & 11 & $18.0 \pm 15.8$ \\
\hline Vitellaria paradoxa & 23 & $2.8 \pm 1.7$ & 9 & $3.6 \pm 5.0$ & 32 & $3.0 \pm 1.7$ \\
\hline
\end{tabular}


Table 3: Number and relative proportion of stems of five main tree species with basal scars according to tree height class. All the values are expressed at $95 \%$ confidence level.

\begin{tabular}{lccccccc}
\hline Tree species & $\begin{array}{c}\text { 2-5m tall } \\
\text { No. of } \\
\text { stems } \\
\text { scarred }\end{array}$ & $\mathbf{\%}$ & $\begin{array}{c}\text { No. of } \\
\text { stems } \\
\text { scarred }\end{array}$ & $\mathbf{\%}$ & $\begin{array}{c}\text { Total } \\
\text { No. }\end{array}$ & $\begin{array}{c}\text { Relative } \\
\text { proportion } \\
(\boldsymbol{\%})\end{array}$ \\
\hline Acacia dudgeoni & 17 & $2.2 \pm 1.8$ & 0 & 0.00 & 17 & $2.2 \pm 1.8$ \\
Burkea africana & 50 & $48.5 \pm 7.0$ & 37 & $80.1 \pm 7.4$ & 87 & $59.4 \pm 4.7$ \\
Combretum adenogenium & 24 & $5.4 \pm 2.6$ & 7 & $10.3 \pm 10.5$ & 31 & $7.3 \pm 1.9$ \\
Detarium microcarpum & 59 & $55.1 \pm 6.0$ & 27 & $63.7 \pm 17.4$ & 86 & $62.6 \pm 5.9$ \\
Vitellaria paradoxa & 26 & $3.4 \pm 1.9$ & 16 & $23.0 \pm 10.5$ & 42 & $6.8 \pm 2.2$ \\
\hline
\end{tabular}

ring in Burkea africana was not significantly different from that in Detarium microcarpum $(t$ $=0.20$; d.f. $=30 ; p>0.5)$. Within tree height, the frequency of scarring was higher in trees measuring $>5 \mathrm{~m}$ tall than trees $2-5 \mathrm{~m}$ high (Table 3 ). The difference in scarring frequency between the two height classes was, however, statistically insignificant for all the five species.

\section{Scar classes}

The results of degree of basal scarring damage assessed in 136 trees measuring $>5 \mathrm{~m}$ tall are summarized in Table 4. The greater proportion of the basal scars was very severe, that is, belonged to class iii (Plate 2). To assess the frequency of the degree of scarring damage statisti-

Table 4: Frequency of basal scar classes in living stems $>5 \mathrm{~m}$ tall in the upper- to middle-slope savanna near Grupe camp in Mole National Park. Class i: up to $1 / 4$ of the tree bole circumference scarred; class ii: $1 / 4-1 / 2$ of the bole circumference scarred; and class iii: $>1 / 2$ of the bole circumference scarred.

\begin{tabular}{ccc}
\hline Scar Class & No. of Stems & \% \\
\hline i) & 12 & 8.8 \\
ii) & 53 & 39.0 \\
iii) & 71 & 52.2 \\
Total & 136 & 100.0 \\
\hline
\end{tabular}

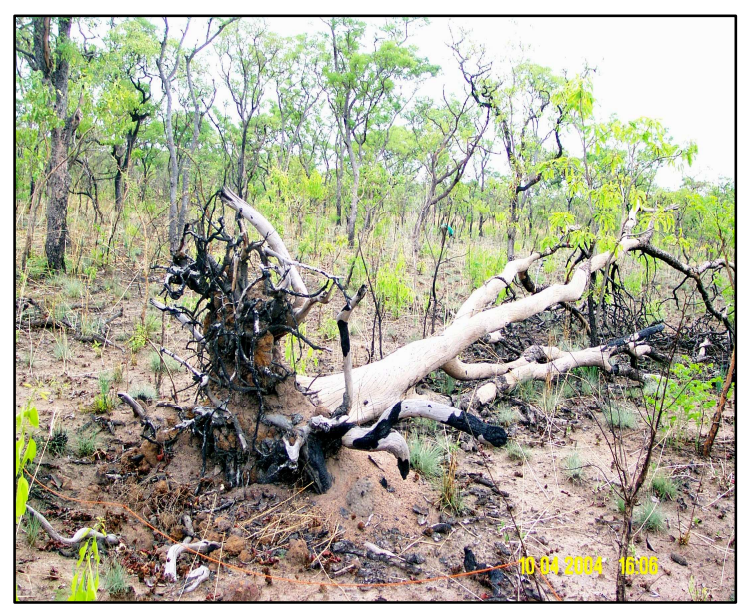

Plate 1: Burkea africana tree toppled by wind and subsequently burnt by fire. Note the tall trees of Burkea africana in the background

cally, a chi-square test of independence was conducted with the expected frequency assigned on the basis of a $33 \frac{1}{3} \%$ probability that the severity of scar damage would be any one of the three classes. The test was highly significant $\left(\chi^{2}=\right.$ 40.34 ; d.f. $=2 ; p<0.001)$, supporting the statement that scar class iii was the most frequent or that a greater proportion of the basal scars had reached an advanced stage. Some of the scars were over $5 \mathrm{~m}$ high (Plate 3), while the majority of them were up to about $1.5 \mathrm{~m}$ high.

42 Journal of Science and Technology, Vol. 28, No. 2, August, 2008 


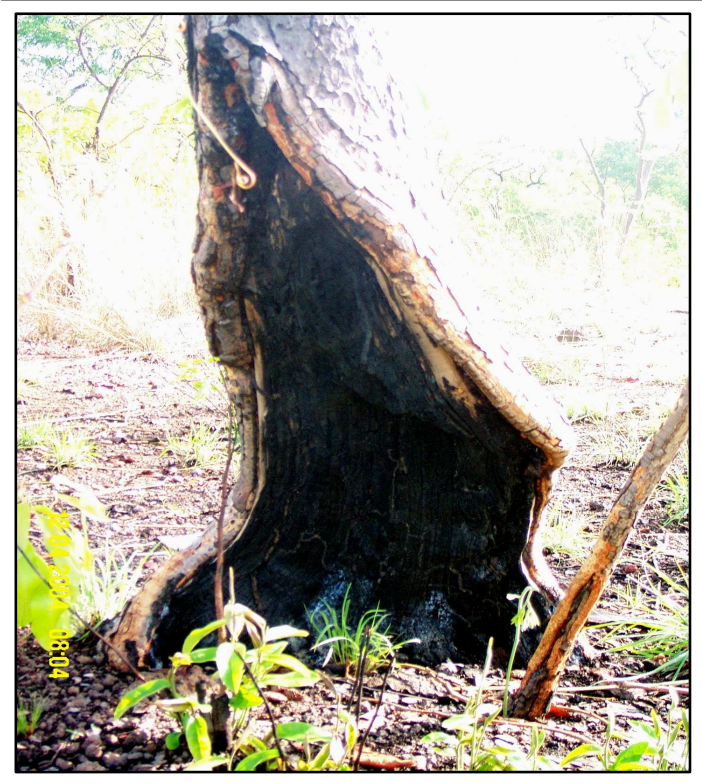

Plate 2: Moribund Detarium microcarpum tree with severe basal scar ('class iii'). Tree may easily be blown over by wind or fall under its own weight

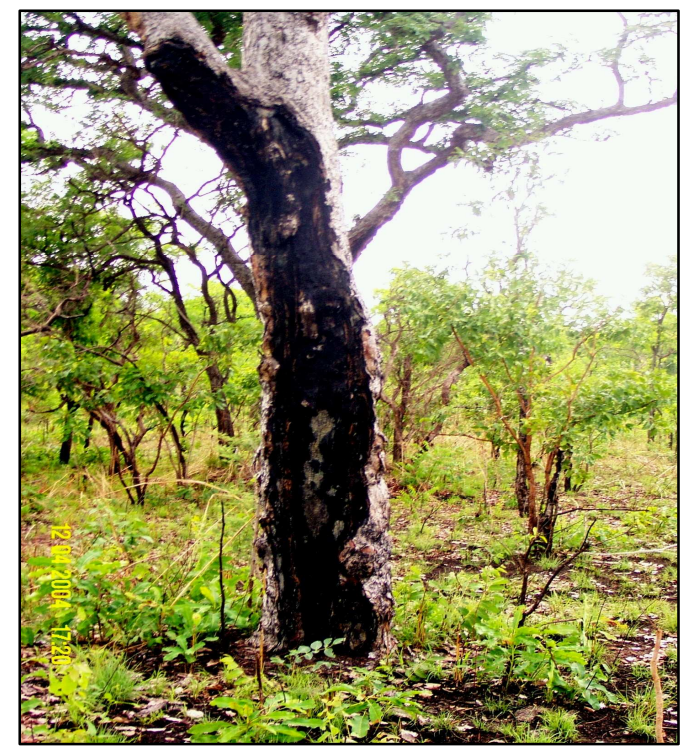

Plate 3: Living Daniellia oliveri tree with severe fire scar. Note the height of the scar from the ground

\section{Scar orientation}

The greater proportion of the scars faced southwest. Approximately $69.8 \%$ of the total sample of 136 basal scars examined for orientation faced southwest, while $18.4 \%$ and $11.8 \%$ faced northeast and south, respectively. To assess the orientation of the 136 scars statistically, a chi-square test of independence was carried out with the expected frequency assigned on the basis of $12.5 \%$ probability that the basal scars would face any one of the eight compass bearings. The test was highly significant $\left(\chi^{2}=446.71\right.$; d.f. $=7 ; p<$ 0.001 ), with the direction southwest accounting for 357.88 of the computed chi-square value, clearly demonstrating that most basal scars tended to face southwest.

\section{DISCUSSION}

Accumulated fire damage on trees and shrubs Tree bark properties (especially thickness), trunk profile and growth rates define strategies of fire resistance in savanna woody species (Gignoux et al., 1997). Most of the tree species found in the study area, notably Burkea africana, Entada africana, Piliostigma thonningii, Pterocarpus erinaceus, Terminalia spp. and Vitellaria paradoxa have been variously described as fire-tolerant, fire -resistant or fire-hardy by several authors (e.g., Trapnell, 1959; Charter and Keay, 1960; Hopkins, 1965; Brookman-Amissah et al., 1980; Pellew, 1983; Dublin et al., 1990; Martin, 1996). Also, several studies (e.g., Trapnell, 1959; Hopkins, 1965; Pellew, 1983) have indicated that woody plants over $3 \mathrm{~m}$ in height are 'safe' from fire-induced mortality, while those up to $3 \mathrm{~m}$ tall are vulnerable to fire mortality. For instance, in the derived savanna zone of the Olokemeji Forest Reserve, of the 8 Burkea africana and 13 Vitellaria paradoxa trees over $5 \mathrm{~m}$ tall subjected to five consecutive years of late dry season burning, none was killed. Only 1 out of 23 trees of Pterocarpus erinaceus died in the same period (Hopkins, 1965). In the Balanites aegyptiaca savanna of the Kidepo Valley National Park, no evidence of fire-induced mortality of mature trees was found under an annual fire regime 
(Harrington and Ross, 1974). Thus fire is generally thought to affect tree recruitment and not adult survival.

Contrary to this generalisation, the present study suggests that large individuals (> $5 \mathrm{~m}$ tall) of fire -resistant savanna woody species can be killed from accumulated fire damage. This is true for all the dominant canopy species, particularly Burkea africana, Detarium microcarpum, Terminalia spp. and Vitellaria paradoxa.

Fire regime is a complex phenomenon, involving several factors including intensity and fire type, i.e. head or back fire. In Mole National Park where mean annual rainfall exceeds 1000 $\mathrm{mm}$, sufficient grass is produced each year to support intense annual wild fires. This is well marked in the savanna near the study area (Grupe Camp) where grass off-take is extremely low and grass biomass is likely to be high due to the limited numbers of elephants and other large mammalian grazers. The grass layer, comprising the more common species such as Hyparrhenia subplumosa, Hyparrhenia chrysargyrea, Andropogon ascinodis and Andropogon schirensis, can reach up to $3 \mathrm{~m}$ high in the rainy season (Hall and Jeník, 1968). Furthermore, in the study area, harmattan winds blowing from the north and northeast in the dry season draws fire burning in the opposite direction into a vortex at the base of large trees, creating a much hotter fire that causes basal scarring damage. Successive intense back fires enlarge the scars until eventually, after several seasons, the tree is killed through the direct action of the fire or toppling by the wind. Large trees are commonly killed by a succession of intense fires. Thus the effects of long-term exposure of woody plants to fire may differ from the expected short-term effects.

At Olokemeji, five consecutive years of burning was apparently too short a period for fire to cause mortality to large trees. Thus a very prolonged period of exposure of large trees to intense back fires most probably accounts for the contrast in the findings of the present study and those of Hopkins (1965) and Harrington and Ross (1974). The findings of the present study, however, agree with the results of Ben-Shahar (1998), which indicated consistent decline in the densities of Baikiaea plurijuga trees of over $8 \mathrm{~m}$ in height due to accumulated fire damage and van der Walt and le Riche (1984), who recorded higher fireinduced mortality in mature trees of Acacia erioloba than in trees of intermediate and small height classes. The present results also agree with the findings of Lonsdale and Braithwaite (1991), which indicated that both the smallest and largest plants of the five most common woody species in the savanna of Kakadu National Park in Australia proved vulnerable to intense fire.

Burkea africana and Detarium microcarpum trees were particularly susceptible to basal scarring damage. Large boles and long exposure to fire impacts most likely accounted for this. It appears that fires in the study area are started from the south and south-western boundary of the Park and spread in a northerly and north-easterly direction. The harmattan wind which blows from the east and north-east during the dry season, creates vortices at tree bole bases opposite to the wind direction. As a result, basal scars occurred predominantly on the south-western side of tree boles in this section of the Park. In order to minimise fire impacts on the vegetation, it would be prudent for the Park's management to burn in the direction of the wind, preferably on less windy days, and also control accidental fires that escape into the Grupe Camp section of the Park from the south-western boundary.

\section{The effects of accumulated fire damage on the composition and structure of the savanna near Grupe camp}

Various authors have reported drastic declines in tree and shrub densities, as well as changes in the relative abundance and composition of woody species due to persistent fires (e.g., Trapnell, 1959; Charter and Keay, 1960; Ramsay and RoseInnes, 1963; Hopkins, 1965; Brookman-Amissah et al., 1980; Lonsdale and Braithwaite, 1991). In

44 Journal of Science and Technology, Vol. 28, No. 2, August, 2008 
Mole National Park, long-term studies in permanent plots will be required to ascertain the effects of the annual fires on the structure and composition of the woody vegetation. However, from these published observations, as well as the findings of the present study, it could be said that changes in the percentage abundance and a general decline in the density of the woody elements of the vegetation in the south-western section of Mole are likely to occur unless burning frequency is reduced.

\section{Implications of the results for other areas of the Park}

Time, transport and accessibility constraints meant that the determinations had to be limited to a relatively small area within the southwestern portion of the Park. A greater number of plots taken from a bigger survey area would have enabled more accurate, park-wide generalizations to be made. Nonetheless, experience gained through research on the effects and use of fire in southern and east African grasslands and savannas (Trollope, 1989; Trollope and Potgieter, 1986; van Wilgen et al., 1990) has led to the conclusion that the broad groups of grasses and trees generally react similarly to different fire regime components. It is, therefore, feasible to extrapolate with some degree of confidence from the findings of this study to the northern half of the Park, from Chasia to Bawena (see Figure 1), where the same components of low grazing pressure and annual intense fires are likely to prevail. But in this section, especially from Chasia to Polzen, wildfires escaping into the Park are likely to be head fires and, therefore, less likely to cause extensive mortality and top-kill to large trees through basal scarring. Therefore, the decline in woody plant density and the consequent vegetation transformation in this section are envisaged to proceed at a slower rate than predicted for the Grupe Camp area.

\section{CONCLUSION}

Perennial dry season fires in the savanna vegetation near Grupe camp of Mole are causing chronic basal scars and widespread mortality and top-kill to large trees. It appears that wind has played a significant role in scarring and killing these trees. Large individuals of canopy tree species with shallow roots, notably Burkea africana are particularly susceptible to toppling by wind just before and during the rainy season. Scarring of tree bole bases was also more frequent in Burkea africana and Detarium microcarpum. The fire impacts are likely to result in changes in the relative abundance of the constituent tree species as well as a decline in the density of woody elements in the plant community as a whole unless burning frequency is reduced. The areas for which these predicted vegetation changes are valid can be generalized to include the vegetation in the northern half of the Park where similar conditions of high fuel load and intense fires are likely to prevail.

\section{ACKNOWLEDGEMENTS}

The authors are deeply indebted to the government of Ghana for funding the research. We are grateful to the Executive Director of the Wildlife Division of Ghana for permission to undertake the field data collection work in Mole National Park. Our thanks are also due the staff of the Park, especially Mr. D. K. Ewur for his hospitality and Mr. A Majeed for his invaluable assistance in the field. This paper has benefited tremendously from discussions with Professor M. R. Ashmore.

\section{REFERENCES}

Ben-Shahar, R. (1998). Changes in structure of savanna woodlands in northern Botswana following the impacts of elephants and fire. Plant Ecology, 136:189-194.

Brookman-Amissah, J., Hall, J. B., Swaine, M. D. and Attakorah, J. Y. (1980). A Reassessment of a fire protection experiment in North-Eastern Ghana savanna. Journal of Applied Ecology, 17: 85-99. 
Charter, J. R. and Keay, R. W. J. (1960). Assessment of the Olokomeji fire-control experiment (Investigation 254) 28 years after institution. Nigeria Forestry Information Bulletin, 3: 1-32.

Dublin, H. T., Sinclair, A. R. E. and McGlade, J. (1990). Elephants and fire as causes of multiple stable states in the Serengeti-Mara woodlands. Journal of Animal Ecology, 59: 1147-1164.

Felfili, J. M., Rezende, A. V., Silva, J. M. C. and Silva, M. A. (2000). Changes in the floristic composition of cerrado sensu stricto in Brazil over a nine-year period. Journal of Tropical Ecology, 16: 579-590.

Frost, P. G. H. and Robertson, F. (1987). The ecological effects of fire in savannas. In: B. H. Walker (ed.). Deterninants of Tropical Savannas, pp. 93-140. IRL Press, Oxford.

Gignoux, J., Clobert, J. and Menaut, J-C. (1997). Alternative fire resistance strategies in savanna trees. Oecologia, 110: 576-583.

Hall, J. B. and Jeník, J. (1968). Contribution towards the classification of savanna in Ghana. Bull. Inst. Fond. Afr. Noire, 30, ser. A, № 1: 84-99.

Harrington, G. N. and Ross, I. C. (1974). The savanna ecology of Kidepo Valley National Park I: The effects of burning and browsing on the vegetation. East African Wildlife Journal, 12: 93-106.

Higgins, S. I., Bond, W. J. and Trollope, W. S. W. (2000). Fire, resprouting and variability, a recipe for grass-tree coexistence in savanna. Journal of Ecology, 88: 213-229.

Hopkins, B. (1965). Observations on savanna burning in the Olokomeji Forest Reserve, Nigeria. Journal of Applied Ecology, 2: 367 -381 .

Hossain, M. and Hall, J. B. (1996). Trees of Mole National Park, Damongo, Ghana $\left(2^{\text {nd }}\right.$ Edition). Ghana Institute of Journalism Press, Accra.
Lonsdale, W. M. and Braithwaite, R. W. (1991). Assessing the effects of fire on vegetation in tropical savannas. Australian Journal of Ecology, 16: 363-374.

Martin, S. C. (1996). The effects of burning on the regeneration of miombo woodland in Kasanga National Park, Zambia. In: P. Riordan and D. Bumham (eds.). Biological Research in Kasanga National Park, Zambia, pp. 1-26. Manchester Metropolitan University, Manchester.

Niering, W. A., Goodwin, R. H. and Taylor, S. (1970). Prescribed burning in Southern New England: Introduction to long-range studies. Proceedings of Annual Tall Timbers Fire Ecology Conference, 10: 267-286.

Pellew, R. A. P. (1983). The impacts of elephant, giraffe and fire upon the Acacia tortilis woodlands of the Serengeti. African Journal of Ecology, 21: 41-74.

Ramsay, J. M. and Rose-Innes, R. (1963). Some quantitative observations on the effects of fire on the Guinea Savanna vegetation of Northern Ghana over a period of eleven years. African Soils, 8: 41-85.

Rutherford, M. C. (1981). Survival, regeneration and leaf biomass changes in woody plants following spring burns in Burkea AfricanaOchna pulchra savanna. Bothalia, 13: 531552.

Sackey, I. (2006). Aspects of the composition and structure of the woody savanna vegetation of Mole National Park, Ghana, with special reference to fire and elephant impacts. Unpublished $\mathrm{Ph}$. D. thesis, University of Bradford.

Sokal, R. R. and Rohlf, F. (1995). Biometry. Freeman, New York.

Trapnell, C. G. (1959). Ecological results of woodland burning experiments in Northern Rhodesia. Journal of Ecology, 47: 129-168.

46 Journal of Science and Technology, Vol. 28, No. 2, August, 2008 
Trollope, W. S. W. (1989). Veld burning as a management practice in livestock production. In: J. E. Danckwerts and W. R. Teague (eds.). Veld management in the Eastern Cape, pp. 67-73. Government Printer, Pretoria.

Trollope, W. S. W. and Potgieter, A. L. F. (1986). Estimating grass fuel loads with a disc pasture meter in the Kruger National Park. Journal of the Grassland Society of Southern Africa, 4:148-152.

Trollope, W. S. W. (1996). Biomass burning in the savannas of Southern Africa with particular reference to the Kruger National Park. In: J. S. Levine (ed.). Global Biomass Burning, pp. 260-269. Massachusetts Institute of Technology Press, Cambridge. van der Walt, P. T. and le Riche, E. A. N. (1984). The influence of veld fire on an Acacia erioloba community in the Kalahari Gemsbok National Park. Koedoe (Supplementary): 103-106.

van Wilgen, B. W., Everson, C. S. and Trollope, W. S. W. (1990). Fire management in southern Africa: Some examples of current objectives, practices and problems. In: J. G. Goldammer (ed.). Fire in the tropical biota: Ecosystem processes and global challenges. Ecological Studies 84. Springer-Verlag, Berlin.

Williams, R. J., Cook, G. D., Gill, A. M. and Moore, P. H. R. (1999). Fire regime, fire intensity and tree survival in a tropical savanna in northern Australia. Australian Journal of Ecology, 24: 50-59. 